\title{
The Effect of Emotional Intelligence and Gender on Writing Proficiency of Iranian EFL Learners
}

\author{
Zohreh Mohammadi \\ Department of English Language Teaching, Zanjan Branch, Islamic Azad University, Zanjan, Iran \\ Siros Izadpanah \\ Department of English Language Teaching, Zanjan Branch, Islamic Azad University, Zanjan, Iran
}

\begin{abstract}
This study examined the relationship between Emotional Intelligence (EI) and mental health on writing proficiency of Iranian EFL learners. The data included two groups of males and females in intermediate and advanced level of English language learning from International Center (IT) and Iran Zamin institutes, Zanjan, Iran. The groups were compared based on their emotional intelligence and mental health on writing proficiency. The participants of this study were Iranian EFL learners. Forty out of 60 completely submitted the questionnaire forms and essay writing task, 21 samples of 40 were males from IT institute and 19 samples were females from Iran Zamin institute. They were asked to fill out the personality questionnaire of EI and writing an essay. The writings were scored by the researchers. The collected data were analyzed using Kolmogorov-Smirnov test and independent T-Test. Overall, the statistical analysis indicated that there was no meaningful relationship between emotional intelligence and writing proficiency between the two groups of men and women. The findings of this study can lead EFL teachers and practitioners to understand the weak and strong points of each individual and, accordingly, make up for the weakness and meet the needs of different individual learners.
\end{abstract}

Index Terms - Emotional Intelligence (EI), gender, writing proficiency

\section{INTRODUCTION}

Linguistic intelligence, emotional intelligence, personality and motivation are different components of language attitude which have effect on learning second language. Among these factors EI plays a critical role in language learning and teaching.

This study was conducted to study the relationship between Emotional Intelligence (EI), gender and writing proficiency. EI is the ability to identify your emotions and manage the emotions of others (Goleman, 1995). People have long been interested in how EI has effect on writing proficiency. The current investigation is an explosion of interest in measuring such individuals 'emotional intelligence which has effect on writing ability. Since emotional intelligence is considered as one of the factors that affect learning, it can be defined as a cognitive skill that exists and influences the way of our thinking.

Since writing is considered as one of the important skills that affect learning, it can be an important ability for all of the students to be successful in school and in the work place. "Writing or composition has been defined in a variety of ways which shows a lack of agreement as to what composition is, and reflects the complexity of the writing process" (Dung, 2004, p. 11). As Heaton (1988) declared writing is a difficult and complex skill to teach requiring grammatical and rhetorical devices (Heaton, 1988). Writing proficiency is discovered by performance on the National Assessment of Educational Progress (NAEP) and it is measured by average scale scores. Writing is an embedded factor in the social and cultural experiences, but rather it is not decontextualized activity in which it is produced (Kern, 2000; Hyland, 2002). Clachar (1999) also says, "Emotion may influence writing strategies" (1999, p.31_60).

With respect to gender, there is no meaningful difference between males and females in emotional social intelligence. Among eight-graders in 2011, the average writing proficiency score for females was 20 points higher than average for males.

The significance of this study is emphasized on the relationship between EI and writing ability. It is worth mentioning here that writing skill was one of the beneficial skills for both students and teachers. Academic writing as a manner of learning skill has been especially perceived as a vital aspect of language ability for effective academic accomplishment. In fact, writing helps to shape and transfer our thoughts to paper. It seems, however, that comprehending this skill is significant for teachers and students. EI has a specific role in constructing and sustaining relationships (Goleman, 1995).

This study is helpful for EFL writing ability to be aware of which components of emotional intelligence are more effective for improvement of their writing skill. According to the complexity of components of EI, it can be noticed that which component is better for males and which is better for females. Identifying learners' emotional abilities in 
instructive program is very important because students' success in understanding themselves during writing will be conceivable.

Furthermore, understanding certain emotional features in this study was important. It is significant that teachers recognize their own emotions and then be familiar with individuals' emotional intelligence. The topic which is chosen was beneficial for the EFL teachers and students who teach and learn in private institutes and public schools. Therefore, the current study attempted to investigate this question empirically and find whether this relation exists between EI and Iranian advanced learners' writing proficiency or not.

Most of the researchers attempt to discover whether any relationship exists between emotional intelligence and students' second language skills such as writing performance. It is important to note that both EI and writing ability play an important role in assessing EFL learners' outcome in educational systems. The problem is unexplored relationship between EI and writing skill, so studying this problem is vital in understanding the relationship with gender differences.

Based on most of the researchers (e.g. Arnold \& Elias, 2006; Daniel Goleman, Tim Shriver, \& Eileen Rockefeller Growald, 1994 ; Elias, 2004), EI is significant in education, so all of its possible effects on learners writing proficiency should be investigated.

According to Chaney (2011), learners who have powerful relationships with their teachers and peers have a strong emotion of self and are more inspired to perform (Chaney, 2011). Attention to this problem in the classroom communities and make relationship will increase learners' writing capability. This study was an empirical investigation into the relationship between emotional intelligence, writing proficiency and gender differences of a few Iranian EFL learners include males and females. The current study tried to shed some insight on the effect of emotional intelligence segments on EFL learners' scholarly implementation in writing performance, together with gender differences in some of the different components relating to EI such as Self-awareness, Self-regulation, Internal motivation, Empathy and Social skills. Therefore, the focus of this study was on a holistic judgment of proficiency in writing. It also aimed to discover if the EI has impact on learners' second language writing performance. The other aim of this study was to examine the effect of gender on advanced students' writing proficiency. Since gender has been considered as one of the variables of the present study, it was studied to investigate the effect of this variable and find out whether or not gender could be an effective variable in individuals' writing performance.

The following research question was formulated to find empirical evidence:

RQ1: Is there any significant relationship between emotional intelligence and writing proficiency of Iranian EFL learners?

In order to fulfill the research question of the study the following hypothesis was formulated:

H01: There is no significant relationship between emotional intelligence and writing proficiency of Iranian EFL learners.

\section{REVIEW OF LITERATURE}

\section{Intelligence}

Intelligence is one of the most important argumentative topics in psychology, so there are different theories to explain the nature of the intelligence. To develop your own intelligence, it is important to understand the evolution of the concept of intelligence. Table 1 reports the intelligence timeline which has been designed by the researcher.

TABLE 1:

INTELLIGENCE TIMELINE

\begin{tabular}{|c|c|c|}
\hline Date & Author & Description \\
\hline 1914 & Stern & $\begin{array}{l}\text { Intelligence is general capacity of an individual consciously to adjust } \\
\text { thinking to new requirements. It is the general mental adaptability to } \\
\text { new problems and conditions of life }\end{array}$ \\
\hline 1914 & Thorndike & $\begin{array}{l}\text { Intelligence is the power of good responses from the point of view of } \\
\text { truth or fact }\end{array}$ \\
\hline 1916 & Lewis Madison Terman & Intelligence is the ability to carry on abstract thinking \\
\hline 1921 & TermanA.Merril & $\begin{array}{l}\text { An individual is the proportion that he is able to carry on abstract } \\
\text { thinking. }\end{array}$ \\
\hline $1924-1973$ & Thurstone & $\begin{array}{l}\text { Intelligence, considered as a mental trait, is the capacity to make } \\
\text { impulses focal at their early, unfinished stage of formation. } \\
\text { Intelligence is therefore the capacity for abstraction, which is an } \\
\text { inhibitory process. }\end{array}$ \\
\hline 1937 & Wagnon & $\begin{array}{l}\text { Intelligence is the capacity to learn and adjust to relatively new and } \\
\text { changing conditions. }\end{array}$ \\
\hline 1941 & Burt & Intelligence is a fixed, inherited ability. \\
\hline 1944 & David Wechsler & $\begin{array}{l}\text { Intelligence is the aggregate or global capacity of an individual to act } \\
\text { purposeful to think rationally, and to deal effectively with his } \\
\text { environment. }\end{array}$ \\
\hline 1948 & Wood worth and Marquis & $\begin{array}{l}\text { Intelligence means intellect put to use. It is the use of intellectual } \\
\text { abilities for handling a situation or accomplishing any task. }\end{array}$ \\
\hline
\end{tabular}




\section{Major Constituents of Intelligence}

Howard Gardner (1983, 1999) supports Thurstone's mentality that intelligence including several forms. Gardner continues Thurstone's study that there is no general intelligence, but rather multiple intelligences. Eight components of Gardner's intelligence including linguistic, logical mathematical, special, musical, bodily- kinesthetic, intrapersonal (self- awareness), interpersonal (other people -awareness) and naturalistic (Gardner, 1999).

Table 2 shows a set of Gardner's multiple intelligence and the brief descriptions of them. Also Robert Sternberg $(1985,1999, \& 2003)$ agrees with Gardner but he believes that there are three types of intelligence; analytical, creative and practical intelligence.

TABLE 2:

GARDNER'S MULTIPLE INTELLIGENCE

\begin{tabular}{l|l}
\hline Definitions & Intelligences \\
\hline The intelligence of words & Linguistic \\
\hline The intelligence of pictures and images & Spatial \\
\hline The intelligence of numbers and reasoning & Logical-mathematical \\
\hline The intelligence of tone, rhythm, and timbre & Musical \\
\hline The intelligence of the whole body and hands & Bodily-kinesthetic intelligence \\
\hline The intelligence of social interactions & Interpersonal intelligence \\
\hline The intelligence of self-knowledge Source: Armsrtong (1993) & Intrapersonal intelligence \\
\hline \multicolumn{2}{c}{}
\end{tabular}

\section{EQ, IQ, SQ}

\section{Intelligence Quotient (IQ)}

How intelligence is utilized within educational systems is an important debatable topic in making decisions among the children. Specifically, Intelligence Quotient (IQ) is a considerable factor to evaluate students' placement into specific education. It is a valuable element to differentiate between individuals' ability (Boring, 1923; Cohen \& Swerdlik, 2005; Groth- Marnat, 2009). Find suitable answer to the question of, "What is intelligence?" is significant that have emerged during the last 100 years. According to Boring (1923), intelligence is the matter that tests test. (p. 35)

There are some important questions about intelligence and IQ testing to evaluate individuals' mental ability and skills. To evaluate individuals' intelligence and IQ understanding the concept of the four questions are necessary. The following figure represenst the four questions of intelligence and IQ testing. Four major questions about Intelligence and IQ testing are:

1. Is intelligence a single ability, or does it involve an assortment of multiple skills and abilities?

2. Is intelligence inherited, or does the environment play a larger role?

3. Are intelligence tests biased?

4. What do intelligence scores predict, if anything?

IQ is used to measure human intelligence to place them in educational settings, occupational performance (Hunter, 1986), academic success (Neisser, 1996) and serve as finders of neurological deficits (Lezak, 2004; Loring\& Bauer, 2010).

Based on psychologists there are different ways to assess human intelligence. One of the most important test to measure intelligence (IQ) is Stanford-Binet Intelligence scale. The test is used to measure psychological ability and intelligence that is utilized to analyze intellectual insufficiencies in young children and adults (Bain \&Allin, 2005).

The purpose of this scale is to help children and adults to recognize their level of intellectual and cognitive abilities in adolescents, adults, children and preschoolers. The Stanford-Binet Intelligence Scale, is also performed in a clinical and educational settings. Different age ranges are manipulated distinct subtests. Thus, it is not measurable for all different age ranges.

Knowledge, quantitative reasoning, visual-spatial processing, working memory and fluid reasoning are five components which are measured by Stanford-Binet Intelligence Scale. Each of these elements is tried in two different spaces of verbal and nonverbal (Visual).

Gottfredson (1997b) pointed that intelligence is the capability to deal with difficulty. However, Carroll (1997) describes intelligence as "the total intellectual repertoire of behavioral responses," "some general property or quality ... of the brain," "reaction-time and physiological measures," "many different information-processing abilities" and "the rate with which learning occurs or the time required for learning."

Scientific researches show that people vary from each other in their capacity to comprehend complex ideas, to deal with impediments thought and to take part in different forms of reasoning. The concept of "intelligence" intents to specify and evaluate this complex set of phenomena.

IQ as general mental ability attempts to illustrate the constitutions of mind which consists of abstract thinking capacity, comprehension, solve the problem and learning (Wall Street Journal, 1994). Ceci (1990) stated that the evaluation of the specialists' intelligence was unimportant in predicting the complexity of thinking at the course on a standard intelligence and IQ testing (p. 43). 
According to most psychology researchers and IQ tests, there are no important differences between males and females. In 2007 Johns and Bouchard administrated 40-60 psychology tests among men and women that found no sex differences in general intelligence.

\section{Spiritual Quotient (SQ)}

In this study EQ is seen as an essential variable, but distinction is made between IQ, SQ and EQ. SQ stand for spiritual quotient which is an essential prerequisite for both IQ and SQ. SQ is the ability to be creative and insightful, to assess that one blueprint is more significant than another, to answer to the fundamental questions. Spiritual intelligence is the human ability to get some information about the importance of life and to experience simultaneously the consistent connection between each of us and the world in which we live (Wolman, 2001).

IQ and EQ help us learn and understand, but SQ help us create. Zohar and Marshall (2000) believe that computer can have a high IQ and animals can have a high EQ, but only human have SQ. These days the concepts of IQ, EQ, and SQ play an important role in the human brain.

Nothawat (2001) through his study, distinguishes three different dimensions of intelligence; Intelligence Quotient (IQ) is the most important test for entrance in educational settings, Emotional Quotient (EQ) is significant for achievement in life and Spiritual Quotient (SQ) is essential for punctual life. According to western psychology (e.g. Zohar \& Marshall) IQ and EQ are an essential part of SQ.

The scientific evidence for SQ has been represented in 90s that there is a God-spot or God Quotient (GQ) in the brain which becomes active when people are discussing and thinking about spiritual topics (Persingers, 1996; Ramchandran, 1999). God quotient is a region in the individuals' brain which is located within neural connections in the temporal lobes (Rendon, 2003). Based on Zohar and Marshal's book (2000) "SQ: the ultimate intelligence", SI is an intelligence that we use for asking basic questions and reconstructing our answers, it helps people to solve important problems.

SQ is a set of capabilities includes both the religious and spiritual resources (Emmons, 1999). Rogers and Yang argued that SQ is a cognitive ability to connection between life-world experience and inner domain of the human mind (Rogers, 2003; Yang, 2006).

As Wolman (2001) stated:

By spiritual, it means the ancient and binding human quest for connectedness with something larger and more trustworthy than our egos - with our own souls, with one another, with the world of history and nature, with the invisible winds of the spirit, with the mystery of being alive:

... Spiritual intelligence can best be seen as a capacity for a particular kind of experience we humans possess, and one for which we also demonstrate certain related abilities. Our task now is to understand how this intelligence can and does influence our lives, how its energy can be harnessed, and how we can come to know ourselves better through spiritual self-direction (pp. 26, 119).

Emotional Intelligence (EI)

EI is accounted to affected individuals' satisfaction, happiness, execution, and their impression of life. The same are at the pith of the positive psychology hypothesis (Bar-On, 2010). With the dawn of $21^{\text {st }}$ century, the term of EI is measured as EQ. EI is a useful factor in anticipating people's performance at home, at work and at educational systems, etc. In early 1990's the concept of emotional intelligence was first discovered by Salovey and Mayer, then supported by Goleman with publication of his book: "Why it can matter more than IQ" in 1995.

Personality trait and ability are two distinct definitions of emotional intelligence. This study admits using the ability model because it is measurable by Scutte Emotional Intelligence Scale. It is only one way to measure EI based on this method. EI is the ability to identify your own emotions and manage the emotions of others (Goleman, 1995). It is a kind of skill to understand other people, what motivates them and how work together for a shared purpose (Howard Gardner, the influential Harvard theorist).

Three main branches of EI by Salovey and Mayer (1990) consist of: 1) appraisal and expression of emotion 2) regulation of emotion 3) utilization of emotion. The third branch of EI contains of four categories, including (1) Flexible Planning (2) Creative Thinking, (3) Redirected Attention, (4) Motivation Goleman conceptualizes emotional intelligence as "the abilities ... which include Self-control, zeal and persistence, and the ability to motivate oneself "... and ..."an old-fashion word for the body of skills that emotional intelligence represents: character" (Goleman, 1995a, p.28).

Goleman says that, "I think you (Reuven Bar-on) maybe ahead of everyone in already developed an EQ scale. This is a promising, pioneering effort in assessing key elements of emotional Intelligence".

Salovey and Mayer (1990) pointed that EI is the subset of social intelligence that includes the ability to monitor a person's emotion and others feelings, to utilize this information to guide one's thinking and activities and to distinguish between them.

EI is the capacity to process emotional information, especially as it includes the perception, assimilation, understanding and management of emotion (Mayer, \& Cobb, 2000). However: Goleman (1997) explains it as a capacity to emphasize and hope; to stimulate oneself and control stimulation in the face of disappointments to regulate people's mind from confusion. Researchers have found that, emotional awareness and ability more that IQ will focus on your success and satisfaction in all kinds of different backgrounds, including family relationships. 
Individuals are better at comparative thinking and creative critical thinking in great dispositions (Salovey, Mayer, Goldman, Turvey, \& Palfai, 1995).

"An emotion occurs when there are certain biological, certain experiential, and certain cognitive states which all occur simultaneously" (Mayer, 1999, p).

According to the Eclopedia of applied psychology (2004) three models of Emotional Intelligence include, (1) ability model, (2) trait model and (3) mixed model that are going to be discussed in the following sections.

\section{Emotional Intelligence Models}

\section{Mayer and Salovey: The Ability Model of EI}

Ability model known as Mayer-Salovey Emotional Intelligence model. This model is the first model that stresses on individuals' emotional information (Mayer \& Salovey; 1997). They also propose that ability EI model is the proficiency to understand, represent and control emotion in the self and other people.

Mayer and Salovey (1997) talk about four branches of EI:

1. Perception of emotion: The ability to recognize and express emotions in oneself and other people as well as in voices, music and other stimuli.

2. Use of emotion to facilitate thinking: The ability to access and generate emotion, use of emotion and feel emotion to communicate feeling.

3. Understanding of emotion: The ability to analyze and understand emotional information. It entails an understanding of the emotional lexicon and the way in which emotions communicate progress, and transition from one to the other.

4. Management of emotion: One of the vital part of EI is the ability to manage emotion, controlling emotions, reacting to the emotions of others.

\section{Trait EI model}

The second model is a trait model developed by Reven Bar-on, focuses on cognitive ability and personality aspects. Trait EI model is "constellation of emotional self- perceptions located at the lower levels of personality (Petrides, Pita \& Kokkinaki, 2007). This model plays a significant role to perceive the intrinsic individuality of emotional skill.

\section{Bar-On: A Mixed Model of EI}

Bar-On outlines five components of emotional intelligence: intrapersonal, interpersonal, adaptability, stress management, and general mood. Table 3 shows all components and sub-components of EI. The model has exhibited utility as far as anticipating administration potential and execution in military reciters (Bar-on, Handley, \& Fund 2006). The model has also been reformed with measures of leadership effectiveness from research manipulated at the center of creative leadership (Bar-on, Handley, \& Fund 2006).

TABLE 3:

BAR-ON'S MODEL OF EMOTIONAL INTELLIGENCE

\begin{tabular}{ll}
\hline Components & Sub-Components \\
\hline Intrapersonal & Self-Regard \\
& Emotional Self-Awareness \\
& Assertiveness \\
\hline Interpersonal & Independence \\
& Self-Actualization \\
\hline Adaptability & Empathy \\
& Social Responsibility \\
& Interpersonal Relationship \\
\hline Stress Management & Reality Testing \\
& Flexibility \\
\hline General Mood Components & Problem Solving \\
& Stress Tolerance \\
\hline
\end{tabular}

\section{Methodology}

\section{Design}

Due to the differing nature of variables in the design of this study, the variables could have different functions in the research question. Also, because of considering the effect of independent variables on the dependent variables, the design of this study is ex-post facto design

\section{Participant}

To understand the effect of the EI and mental health on writing proficiency better, the researchers administrated questionnaire of emotional intelligence and an essay writing task among the 60 students of English language learning from IT and Iran Zamin institutes, Zanjan, Iran. Forty out of 60 participants completely submitted the questionnaire 
forms and wrote an essay with a certain topic, 19 samples of 40 were females from IT and 21 were males from Iran Zamin institute. Participants were selected from 5 classes that each included of approximately 8 students.

The researchers selected the same topic for all participants to write about, students kept their essays in individual portfolios which they took home during and at the end of the week students returned their papers. Researchers began collecting data in approximately two weeks to give students opportunity to have a body of writing. Before conducting research, researcher had to gain permission from both mangers in the IT and Iran Zamin institutes. It was necessary to gain approval to ensure that the research did not have any harmful effect on our samples.

Instrument

Two different types of instruments were used in this paper. The first instrument was the questionnaire which consisted of 33-item to test participant's emotional Intelligence. The items consisted of four categories. Ten items were related to perception of Emotion; 9 items were related to managing own emotion; 8 items were regarded to managing others' emotion, and 6 items were related to utilizing of emotion. The second instrument was essay writing to evaluate participant's writing proficiency. Two criteria were considered to grade the participant's essay writing which were sentence structure and grammar, the items composing the subscales were as follows: Use of variety of sentence structure and overall grammar.

\section{Data collection}

The data were collected in two places in IT and Iran Zamin institutes in Zanjan,, Iran. Questionnaires were distributed among the participants in intermediate and advanced level of English language learning .To better understanding the researcher explained the nature of the questionnaire and translated (backward and forward translation by experts) all items from English to Persian with loud voice to all participants and also explained how they should fill out the forms and asked them to write their age and name.

\section{Data Analysis}

The data collected fed into SPSS to get descriptive output as Mean and Standard Deviations (SD). Kolmogorov Smirnov test and independent t-test were utilized to emotional scales and its subscales.

\section{RESULTS AND DiSCUSSION}

A one sample Kolmogorov-Smirnov test was conducted to check the normality of distribution of the scores. The Kolmogorov-Smirnov test estimates the parameters from the sample. The sample mean and standard deviation were the parameters for a normal deviation, the sample mean was the parameter for the poison distribution, and the sample mea $\mathrm{n}$ was the parameter for the exponential distribution. This study empirically investigated the relationship between EI/ mental health and writing proficiency of Iranian English language learners within the two groups of males and females. For this aim 33-item EI scale and an essay writing task were administrated to the participants. The collected data were analyzed using of SPSS 19. To conduct the normal distribution of the scores, one sample Kolmogorov-Smirnov test was used to gain scores in SPSS. The distribution was decided normal since the p-value (o. 55>0.05). As it can be seen in table 4 , the data followed the poison distribution $(\mathrm{D}=.125, .142, .126$ and .124 respectively for variables; perception of Emotion, managing own emotion, managing other emotion and utilization of Emotion, $\mathrm{N}=40$ each, and p>0.05 each).

TABLE 4:

ONE-SAMPLE KOLMOGOROV-SMIRNOV TEST FOR DISTRIBUTION CHECKING

\begin{tabular}{|c|c|c|c|c|c|}
\hline & & Perception of Emotion & Managing own Emotions & Managing Other's Emotions & Utilization of Emotion \\
\hline $\mathrm{N}$ & & 40 & 40 & 40 & 40 \\
\hline \multirow[t]{2}{*}{ Normal Parameters ${ }^{\mathrm{a}, \mathrm{b}}$} & Mean & 3.4405 & 3.6333 & 3.7116 & 3.6767 \\
\hline & Std. Deviation & .49894 & .53431 & .58437 & .68804 \\
\hline \multirow[t]{3}{*}{ Most Extreme Differences } & Absolute & .125 & .142 & .126 & .124 \\
\hline & Positive & .093 & .086 & .099 & .075 \\
\hline & Negative & -.125 & -.142 & -.126 & -.124 \\
\hline Kolmogorov-Smirnov Z & & .793 & .899 & .798 & .782 \\
\hline Asymp. Sig. (2-tailed) & & .555 & .394 & .547 & .573 \\
\hline
\end{tabular}

The T-Test was evaluated to determine the significant differences between male and female on EL. Table 5 provided useful descriptive statistics for two groups of male and female, including the mean and standard deviation. As the table 5 showed ,the participants were 21 males and 19 females $(\mathrm{N}=40)$. The descriptive analysis of the subjects were presented in table4. The result showed that males' mean score was more than females' score on the perception of emotion, managing own emotion and utilizing of emotion while scores on managing others' emotions were approximately the same. 
TABLE 5:

DESCRIPTIVE STATISTICS FOR EI VS. GENDER AS TWO INDEPENDENT VARIABLES

\begin{tabular}{|ll|l|l|l|l|}
\hline \multicolumn{2}{c}{ Gender } & N & Mean & Std. Deviation & Std. Error Mean \\
\hline Perception of Emotion & Male & 21 & 3.5150 & .54089 & .11803 \\
& Female & 19 & 3.3582 & .44798 & .10277 \\
\hline Managing own Emotions & Male & 21 & 3.7895 & .49748 & .10856 \\
& Female & 19 & 3.4606 & .53258 & .12218 \\
\hline Managing Other's Emotions & Male & 21 & 3.7126 & .57976 & .12651 \\
& Female & 19 & 3.7105 & .60532 & .13887 \\
\hline Utilization of Emotion & Male & 21 & 3.7222 & .62515 & .13642 \\
& Female & 19 & 3.6263 & .76575 & .17567 \\
\hline
\end{tabular}

Table6 indicated that there were two parts of the output, levenes' test for equality of variances and t-test for equality of means. The table 6 below depicted the results for the t-test independent samples. As it can be seen, the obtained pvalue (sig.) was higher than 0.05 meant that the variability in conditions was approximately the same. It meant that the variability in the conditions was not significantly different, which was a good.Table6 also showed the sig.2-tailed values are higher than 0.05 in perception of emotion, managing others' emotion and utilizing emotion which meant there was no statistically significant differences between males and females, while it was approximately equal to 0.05 in managing own emotion which meant there are significant differences between male and female of EI.

\begin{tabular}{|c|c|c|c|c|c|c|c|c|c|c|}
\hline & & \multicolumn{2}{|c|}{$\begin{array}{c}\text { Levene's Test for Equality of } \\
\text { Variances }\end{array}$} & \multicolumn{7}{|c|}{ t-test for Equality of Means } \\
\hline & & \multirow[b]{2}{*}{$\mathrm{F}$} & \multirow[b]{2}{*}{ Sig. } & \multirow[b]{2}{*}{$t$} & \multirow[b]{2}{*}{$d f$} & \multirow[b]{2}{*}{ Sig. (2-tailed) } & \multirow[b]{2}{*}{ Mean Difference } & \multirow[b]{2}{*}{$\begin{array}{l}\text { Std. Error } \\
\text { Difference }\end{array}$} & \multicolumn{2}{|c|}{$\begin{array}{l}95 \% \text { Confidence Interval of the } \\
\text { Difference }\end{array}$} \\
\hline & & & & & & & & & Lower & Upper \\
\hline Perception of Emotion & $\begin{array}{r}\text { Equal variances assumed } \\
\text { Equal variances not } \\
\text { assumed }\end{array}$ & 1.177 & 285 & $\begin{array}{l}.992 \\
1.002\end{array}$ & 38 & $\begin{array}{l}.327 \\
.323\end{array}$ & $\begin{array}{l}.15678 \\
.15678\end{array}$ & $\begin{array}{l}.15801 \\
.15651\end{array}$ & $\begin{array}{l}-.16309 \\
-.16013\end{array}$ & $\begin{array}{l}.47665 \\
.47368\end{array}$ \\
\hline Managing own Emotions & $\begin{array}{r}\text { Equal variances assumed } \\
\text { Equal variances not } \\
\text { assumed }\end{array}$ & .069 & .794 & $\begin{array}{l}2.019 \\
2.012\end{array}$ & 38 & $\begin{array}{l}.051 \\
.052\end{array}$ & $\begin{array}{l}32886 \\
32886\end{array}$ & $\begin{array}{l}.16287 \\
.16344\end{array}$ & $\begin{array}{l}-.00086 \\
-.00233\end{array}$ & $\begin{array}{l}.65858 \\
.66005\end{array}$ \\
\hline Managing Other's Em otions & $\begin{array}{r}\text { Equal variances assumed } \\
\text { Equal variances not } \\
\text { assumed }\end{array}$ & 710 & .405 & .011 & 38 & $\begin{array}{l}.991 \\
.991\end{array}$ & $\begin{array}{l}.00206 \\
.00206\end{array}$ & $\begin{array}{l}.18744 \\
.18786\end{array}$ & $\begin{array}{l}-.37740 \\
-.37851\end{array}$ & $\begin{array}{l}38152 \\
38262\end{array}$ \\
\hline Utilization of Emotion & $\begin{array}{r}\text { Equal variances assumed } \\
\text { Equal variances not } \\
\text { assumed }\end{array}$ & 1.804 & .187 & .436 & 38.849 & $\begin{array}{l}.666 \\
.669\end{array}$ & .09591 & .22015 & $\begin{array}{l}-.34976 \\
-.35570\end{array}$ & $\begin{array}{l}54158 \\
54752\end{array}$ \\
\hline
\end{tabular}

TABLE 7:

THE CANDIDATES' WRITHING PROFICIENCY SCORES

\begin{tabular}{|ll|l|l|l|l|}
\hline & Frequency & Percent & Valid Percent & Cumulative Percent \\
\hline Valid & 1 & 10 & 25.0 & 25.0 & 25.0 \\
& 2 & 7 & 17.5 & 17.5 & 42.5 \\
& 3 & 5 & 12.5 & 12.5 & 55.0 \\
4 & 14 & 35.0 & 35.0 & 90.0 \\
5 & 4 & 10.0 & 10.0 & 100.0 \\
& Total & 40 & 100.0 & 100.0 & \\
\hline
\end{tabular}

Table 8 showed the relationship between the scores and variables. Pearson correlation was used to peruse the relationship between them. SPSS19 will output a cross tabulation table that included a value for Pearson correlation and a 2-tailed significance value. If value of "sig." reported was equal to or less than 0.05 (at the $95 \%$ level of confidence) or 0.01 (at the $99 \%$ level of confidence), the correlation was significant and the null hypothesis was rejected. Thus table 
8 indicated that there was a significant correlation between perception of emotion and utilization of emotion at the 0.05 level while according to the result there was a meaningful correlation between managing own emotion and managing other's emotion at the 0.01 level. As a result the correlation between two variables, perception of emotion and managing own emotion and also the correlation between managing others' emotion and utilizing of emotion was positive.

As shown in table 8, the correlation between perception of emotion and writing proficiency score was ".169" and pvalue is ".298", the correlation between managing own emotion and score was ".212" and p-value was ".189",the correlation between managing other's emotion and writing proficiency score was ". 327 " and p-value was ".040" which meant their relationship was significant at the 0.05 level and finally the correlation between utilization of emotion and score was ".205" and p-value was ".203". The correlation can range from -1 to +1 , with -1 indicating a perfect negative correlation, +1 indicating a perfect positive correlation, and zero indicating no correlation at all.

TABLE 8:

CORRELATION ANALYSES AMONG EI SUB-SCALES AND WRITING PROFICIENCY SCORES

\begin{tabular}{|c|c|c|c|c|c|c|}
\hline & & $\begin{array}{l}\text { Perception of } \\
\text { Emotion }\end{array}$ & $\begin{array}{l}\text { Managing own } \\
\text { Emotions }\end{array}$ & $\begin{array}{l}\text { Managing Other's } \\
\text { Emotions }\end{array}$ & $\begin{array}{l}\text { Utilization of } \\
\text { Emotion }\end{array}$ & Score \\
\hline \multirow{3}{*}{$\begin{array}{l}\text { Perception of } \\
\text { Emotion }\end{array}$} & Pearson Correlation & 1 & $.731^{* *}$ & $.511^{* *}$ & $.373^{*}$ & .169 \\
\hline & Sig. (2-tailed) & & .000 & .001 & .018 & .298 \\
\hline & $\mathrm{N}$ & 40 & 40 & 40 & 40 & 40 \\
\hline \multirow{3}{*}{$\begin{array}{l}\text { Managing own } \\
\text { Emotions }\end{array}$} & Pearson Correlation & $.731^{* *}$ & 1 & $.587^{* *}$ & $.575^{* *}$ & .212 \\
\hline & Sig. (2-tailed) & .000 & & .000 & .000 & .189 \\
\hline & $\mathrm{N}$ & 40 & 40 & 40 & 40 & 40 \\
\hline \multirow{3}{*}{$\begin{array}{l}\text { Managing Other's } \\
\text { Emotions }\end{array}$} & Pearson Correlation & $.511^{* *}$ & $.587^{* *}$ & 1 & $.604^{* *}$ & $.327^{*}$ \\
\hline & Sig. (2-tailed) & .001 & .000 & & .000 & .040 \\
\hline & $\mathrm{N}$ & 40 & 40 & 40 & 40 & 40 \\
\hline \multirow{3}{*}{$\begin{array}{l}\text { Utilization of } \\
\text { Emotion }\end{array}$} & Pearson Correlation & $.373^{*}$ & $.575^{* *}$ & $.604^{* *}$ & 1 & .205 \\
\hline & Sig. (2-tailed) & .018 & .000 & .000 & & .203 \\
\hline & $\mathrm{N}$ & 40 & 40 & 40 & 40 & 40 \\
\hline \multirow[t]{3}{*}{ Score } & Pearson Correlation & .169 & .212 & $.327^{*}$ & .205 & 1 \\
\hline & Sig. (2-tailed) & .298 & .189 & .040 & .203 & \\
\hline & $\mathrm{N}$ & 40 & 40 & 40 & 40 & 40 \\
\hline
\end{tabular}

\section{CONCLUSION}

The purpose of this study was to find the effect of the Emotional Intelligence (EI) and mental health on writing proficiency of Iranian EFL learners. EI is a capacity to understand your own emotions and manage other's emotions. Writing proficiency is an important part of communication. Writing is a more active process than other skills such as reading, speaking and listening. The result suggests that there is a loose relationship between writing proficiency and EI. Even if there is not a significant correlation between EI and writing proficiency, it could be an indirect effect on writing skills. A positive outcome of this study was the finding that only there is a significant correlation between managing other's emotion and writing proficiency scores at the 0.05 level. Moreover, based on the result, there is no significant difference between passion of men and women. In fact, writing about positive experiences improved individual's happiness and health. In other words, creating positive emotion can have a positive effect on writing proficiency.

\section{APPENDiX. Emotional InTELLIGENCE SCALE}

Perception of Emotion (items 5, 9, 15, 18, 19, 22, 25, 29, 32, 33)

Managing Own Emotions (2, 3, 10, 12, 14, 21, 23, 28, 31)

Managing Others' Emotions (1, 4, 11, 13, 16, 24, 26, 30)

Utilization of Emotion (6, 7, 8, 17, 20, 27)

Directions: Each of the following items asks you about your emotions or reactions associated with emotions. After deciding whether a statement is generally true for you, use the 5-point scale to respond to the statement. Please circle the " 1 " if you strongly disagree that this is like you, the " 2 " if you somewhat disagree that this is like you, " 3 " if you neither agree nor disagree that this is like you, the " 4 " if you somewhat agree that this is like you, and the " 5 " if you strongly agree that this is like you. There is no right or wrong answers. Please give the response that best describes you.

$1=$ strongly disagree

$2=$ somewhat disagree

$3=$ neither agree nor disagree 
4=somewhat agree

$5=$ strongly agree

1. I know when to speak about my personal problems to others. 12345

2. When I am faced with obstacles, I remember times I faced similar obstacles and overcame them. 12345

3. I expect that I will do well on most things I try. 12345

4. Other people find it easy to confide in me. 12345

5. I find it hard to understand the non-verbal messages of other people. 12345

6. Some of the major events of my life have led me to re-evaluate what is important and not important. 12345

7. When my mood changes, I see new possibilities. 12345

8. Emotions are one of the things that make my life worth living. 12345

9. I am aware of my emotions as I experience them. 12345

10. I expect good things to happen. 12345

11. I like to share my emotions with others. 12345

12. When I experience a positive emotion, I know how to make it last. 12345

13. I arrange events others enjoy. 12345

14. I seek out activities that make me happy. 12345

15. I am aware of the non-verbal messages I send to others. 12345

16. I present myself in a way that makes a good impression on others. 12345

17. When I am in a positive mood, solving problems is easy for me. 12345

18. By looking at their facial expressions, I recognize the emotions people are experiencing. 12345

19. I know why my emotions change. 12345

20. When I am in a positive mood, I am able to come up with new ideas. 12345

21. I have control over my emotions. 12345

22. I easily recognize my emotions as I experience them. 12345

23. I motivate myself by imagining a good outcome to tasks I take on. 12345

24. I compliment others when they have done something well. 12345

25. I am aware of the non-verbal messages other people send. 12345

26. When another person tells me about an important event in his or her life, I almost feel as though I experienced this event myself. 12345

27. When I feel a change in emotions, I tend to come up with new ideas. 12345

28. When I am faced with a challenge, I give up because I believe I will fail. 12345

29. I know what other people are feeling just by looking at them. 12345

30. I help other people feel better when they are down. 12345

31. I use good moods to help myself keep trying in the face of obstacles. 12345

32. I can tell how people are feeling by listening to the tone of their voice. 12345

33. It is difficult for me to understand why people feel the way they do. 12345

\section{REFERENCES}

[1] Bain, S.K., \&Allin, J.D. (2005). Stanford-Binet Intelligence Scales, Fifth Edition. Journal of Psychoeducational Assessment, 23(1), 87-95.

[2] Bar-On, R. (2010). Emotional intelligence: an integral part of positive psychology. South African Journal of Psychology, 40(1), 54-62.

[3] Bar-On, R., Handley, R., \& Fund, S. (2006). The impact of emotional intelligence on performance. Linking emotional intelligence and performance at work: Current research evidence with individuals and groups, 3-19.

[4] Bar-On, R. (2006). The Bar-On model of emotional social intelligence (ESI). Psichothema, 18, 13-25.

[5] Bar-on,R. (2004). The Bat-on Emotional Quotient Inventory (EQ-i): Rational, description and psychometric properties. In G. Gender (Ed.), measuring emotional intelligence: common ground and controversy Hauppauge, NY: Nova science.

[6] Bar-on, R. (1980). The emotional quotient inventory (EQ-i): a test of emotional intelligence. Toronto: multi-Health system.

[7] Bar-on, R. (2006). The model of emotional-social intelligence (ESI). Psicothema 18, supple, 13-25.

[8] Bar-on, S. (2003). The essential differences: The male and female brain. Phikappa phi forum 85, 22-26.

[9] Bar-on, Cohen, S. (2005). Gender differences in emotional intelligence. Psychological studies 51 (4), 261-268.

[10] Braberry, T., \& Greves, J. (2009).Emotional intelligence 2.0.USA: Talentsmart.

[11] Burt, C.L. (1941). The factors of the Mind, New York: Macmillan.

[12] Boring, E. G. (1923). Intelligence as the tests test it. New Republic, 34, 34-37.

[13] Carroll, J. B. (1993). Human cognitive abilities: A survey of factor-analytic studies. New York: Cambridge University Press.

[14] Ceci, S.J. (1990). On Intelligence... More or Less: A Bioecological Treatise on Intellectual Development. Prentice-Hall Englewood Cliffs, New Jersery.

[15] Chaney, S. (2011). Writer's workshop: Implementing units of study, findings from a teacher study group, and student success in writing. Retrieved July 16, 2017 from http://www.eric.ed.gov/PDFS/ED520323.pdf.

[16] Clachar, A. (1999). It is not just cognition: The effect of emotion on multiple-level discourse processing in second-language writing. Language Science, 21, 31-60. 
[17] Cohen, R. J., \& Swerdlik, M. E. (2005). Psychological testing and assessment: an introduction to tests and measurement (sixth ed.). New York: Mc Graw Hill.

[18] Elias M.J. (2004). The connection between social emotional learning and learning disabilities: Implications for intervention. Learning Disability Quarterly. 27:53-64.

[19] Elias M.J., \& Arnold J. (2006). The educator's guide to emotional intelligence and academic achievement. Cor win Press, Thousand Oaks, CA

[20] Emmons, R. A. (1999). The psychology of ultimate concerns: Motivation and spirituality in personality. New York: Guilford

[21] Gardner, H. (1983). Frames of Mind. New York: Basic Book, Inc.

[22] Gardner, H. (1999). Intelligence reframed: Multiple intelligences for the 21century. New York: Basic Books.

[23] Groth- Marnat, G. (2009). Handbook of Psychological Assessment. Hoboken, New Jersey: John Wiley\&Sons,Inc.

[24] Goleman, D. (1995a). Emotional Intelligence. New York: Bantam Books.

[25] Gottfredson, Linda S. (1997b), "Why g matters: The complexity of everyday life", Intelligence24: 79-132, doi: 10.1016/S01602896(97)90014-3.

[26] Heaton, J. B. (1988). Writing English language tests. New York: Longman.

[27] Howard, G. (1993). The theory of multiple intelligence. New York, NY: Basic books.

[28] Hyland, K. (2002). Theories and perspectives on intercultural communication. 14(2): 139-142.

[29] Hunter, J. E. (1986). Cognitive ability, cognitive aptitudes, job knowledge, and job performance. Journal of Vocational Behavior, 29(3), 340-362. doi: 10.1016/0001-8791(86)90013-8.

[30] Kern, R. (2000). Literacy and language teaching. Hong Kong: Oxford University Press.

[31] Lezak, M., D. (2004). Neuropsychological assessment. Oxford: Oxford University Press.

[32] Loring, D. W., \& Bauer, R. M. (2010). Testing the limits: Cautions and concerns regarding the new Wechsler IQ and Memory scales. Neurology, 74, 685- 690.

[33] Mayer, J. D., Salovey, P., \& Caruso, D. (2000). Models of emotional intelligence. Handbook of intelligence, 2, 396-420.

[34] Mayer, J.D. (1999). Emotional intelligence: popular or scientific psychology? APA Monitor, 30(8), September. Retrieved July 16, 2017 from Online: http://www.apa.org/monitor/sep99/sp.html.

[35] Mayer, J. D., \& Salovey, P. (1997). What is emotional intelligence: In P. Salovey \& D. Sluyter (Eds), Emotional development and emotional intelligence: Implications for educators. New York: Basic Books, pp. 3-31.

[36] Neisser, U., Boodoo, G., Bouchard, T., Brody, N., Ceci, S. J., Halpern, D. F., Urbina, S. (1996). Intelligence: Knowns and unknowns. American Psychologist, 51(2), 77- 101.

[37] Persinger, M. A. (1996). Feelings of past lives as expected perturbations within neurocognitive processes that generate the sense of self: Contributions fromlimbic labiality and vectorial hemisphericity. Perceptual and Motor Skills, 83(2), $1107-1121$. Handbook of Emotional Intelligence. Cambridge, MA: Hogrefe\& Huber.

[38] Petrides, K. V., Pita, R., \&Kokkinaki, F. (2007).The location of trait emotional intelligence in personality factor space. British Journal of Psychology, 98, $273-289$.

[39] Ramachandran, V. S. (1999). Phantoms in the brain: Exploring the mysteries of the human brain. London: Fourth Estate.

[40] Rendon, R. G. (2003). A Systematic Approach to Assessing Organizational Contract Management Maturity. Unpublished doctoral dissertation, School of Business, Argosy University, Orange County, CA.

[41] Rogers, J. L. (2003). Preparing spiritual leaders: One teacher takes on the challenge. About Campus, 8(5), 19-26.

[42] Salovey, P., and Mayer, J. D. (1990). Emotional intelligence. Imagination, Cognition, and Personality, 9, 185-211.

[43] Salovey, P., Mayer, J. D., Goldman, S. L., Turvey, C., \&Palfai, T. P. (1995). Emotional attention, clarity, and repair: Exploring emotional intelligence using the trait meta-mood scale. In J. W. Pennebaker (Ed.), Emotion, disclosure, and health (p.125-154). Washington, DC: APA.

[44] Sternberg, R. J. (1985). Beyond IQ: A triarchic theory of human intelligence. New York, USA: Cambridge University Press

[45] Sternberg, R. J. (1999a). Intelligence as developing expertise. Contemporary Educational Psychology, 24, 359-375.

[46] Sternberg, R. J. (1999b). A propulsion model of types of creative contributions. Review of General Psychology, 3, 83-100.

[47] Sternberg, R. J. (1999c). The theory of successful intelligence. Review of General Psychology, 3, 292-316.

[48] Sternberg, R. J. (Ed.). (2003). The anatomy of impact: What has made the great works of psychology great? Washington, DC, USA: American Psychological Association.

[49] Sternberg, W. (1914). The psychological methods of testing intelligence (G. M. Whipple, Trans.). Baltimore: Warwick \& York. (Original work published, 1912)

[50] Terman, Lewis M. (1916).The Measurement of Intelligence: An Explanation of and a Complete Guide for the use of the Stanford Revision and Extension of the Binet-Simon Intelligence Scale. Boston. Houghton Mifflin Co.

[51] Terman, L. M. (1921) "II. Intelligence and its measurement: A symposium", Journal of Educational Psychology, 12, $127-133$.

[52] Thorndike, E. L. (1914). Educational Psychology: Briefer Course. New York: Teachers College, Columbia University.

[53] Woodworth, R.S., and Marquis, D.G. (1948). Psychology, Henry Holt, New York.

[54] Wolman, R. W. (2001). Thinking with your soul: Spiritual intelligence and why it matters. New York: Harmony Book.

[55] Yang, K. (2006). The spiritual intelligence of nurses in Taiwan. Journal of Nursing Research, 14(1), 24-35.

[56] Zohar, D. \& Marshall, I. (2000). SQ: Spiritual intelligence the ultimate intelligence. London: Bloomsbury Publishing. 


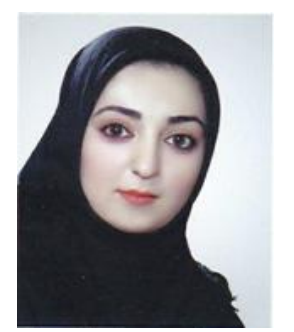

Zohreh Mohammadi was born in Zanjan, Iran, in 1990. She received M.A. degree in Teaching English as a Foreign Language (TEFL) from Islamic Azad University of Zanjan, in 2015. Since 2009, she has worked as a translator and English teacher. She has taught English in Zanjan and Qom private language institutions. Her professional interests are teaching English and second language acquisition.

Siros Izadpanah received Ph.D. in Teaching English as a Foreign Language (TEFL). He has been teaching in Azad University of Zanjan for 15 years. He has compiled seven books for university students and published many articles in international journals and conferences. 